\title{
MORPHOLOGICAL STUDY ON THE MEMBRANOUS LABYRINTH OF THE COCHLEA BY MEANS OF A PHASE CONTRAST MICROSCOPE
}

By

T. WATANABE

\section{From the Department of Oto-Rhino-Laryngology, Faculty of Medicine, Tohoku Uuiversity,} Sendai (Director: Prof. Y. Tsuiki)

By the use of a phase contrast microscope, the author examined the structure of fresh membranous labyrinth of guinea pig.

Observations were summarised as fallows:

1) The inner and outer hair cells and their supporting cells were respectively separated from Organ of Corti by means of micro-surgical technique, and their fine structures were observed.

2) The basilar, reticular, tectorial and Reissner's membarnes and vascular stria were respectively separeted from cochlear canal. Their constructions were observed.

3) Particularly, hairs of sensory cells were examined in detail. It might be stated from this observation that the forms and distribution of hairs are different in respective portions of the spiral turn of cochlea.

The anthor concluded from the mor phological observation described above, that the hairs of sensory cells play an important rôle in the analytic mechanism of sound frequency in the inner ear.

\section{位相差顕微鏡による新鮮蝸牛膜様迷路の形態学的研究}

\section{東北大学医学部耳睤咽渎科学教室（主任：立木豐教授）}

渡辺草勤

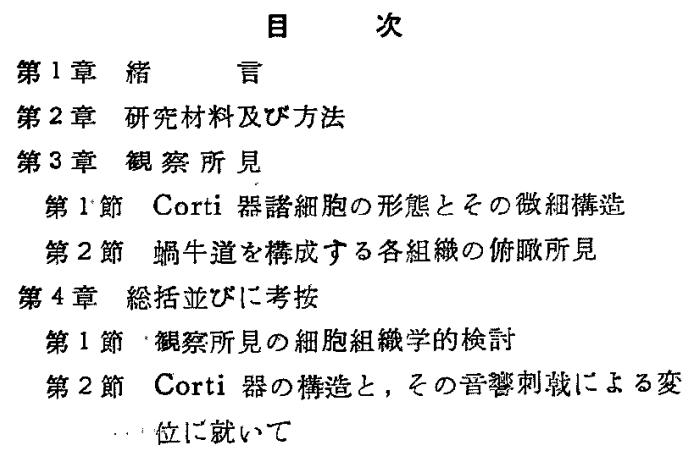

第 3 節 聴毛形態と周波数分析能に就いて

第 5 章 結 論

\section{第1章. 緒言}

聴器迷路の形態学的研究は, 1852 年 Corti 器が発見 されて以来今日迄，主として組織学的立場から綂けら れてきたが，この間， Reissner，Deiters, Hensen,
Claudius 等の同名細胞の発見, Retzius の背椎動物聴: 器に関寸る広範な研究，更に Kolmer, Held, Wittmaack 等の詳細な検索があり, 又 1908年には Nager-吉 䒠の生体固定法の改良等があつた。そして約一世紀を経 た今日に和いては，内耳組織搆造の大構は汪ら゙解明され た観がある。

しかしながら，複雑な立体構造を持つ迷路形態恃，必 ずしるこれだけで究明し得るすのではなく、殊に㯖覚機 構の立昜からその微細構造を追求する時, 微小炕して巧 妙な迷路感覚装置の中に，末だ数多くの謎が䟤められて いるのに気が付く。

このことは勿論, 聴器構造の持つ複雑微妙さに起因し ているが，区面従来の研究方法の限界をも指摘するもの であつて，むは快固定切片標本だけでは，その充分な解

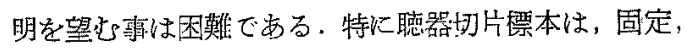
脱灰, 脱水及び包埋等の物理化学的諸操作を経て作られ 
たものでありそこに表現される所の組緀像は，浃して 生体聴器の実体を現しているとは言えない。

まして生体細胞は約 $80 \%$ の水分を含さと云われてお りこれが脱水によって迷路形態乙与える影響は，盖乙 甚大劣ものがある思われる。

しかるに近年, 我ふは位相差顕微鏡の出現によつて, 生の組織, 生きた細胞の状態安, 無固定, 無染色のま で，比較的容易に且つ明降に観察できるようになつた．

こつにおいて私は，この位顕を応用して脵様迷路の生 㦘㨞造の究明を思い立ら，先ず螖牛迷跎の組澈細胞に就 いてその新解時に括ける状堭を観察追求し，百にこれを 従来の固定切片像と比較検討してみた。 その結果, 蝸 牛組職就中 Corti 器の構造に 関し, 聴覚機構上與味 ある幾つかの知見を得る事ができたので以下埇告した い.

\section{第2章 研究材料及び方法}

実験には主として海犋，一部家鬼を使用したが、その蝸 牛殼を，生体動物から直接，あるいは断頭後に摘出して リンゲル氏液に投入し，これを実体顕微鏡下に掋大解剖 しながら迷路軟部組職を分離した（写真 $\mathrm{i}$ ).

次ぎにこれをスシイドガラスの上に拾い上げ、リンゲ

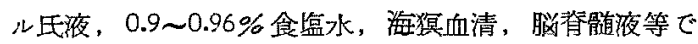
封じて新鮮摽本とした。

検索には位相美顕微鏡を使用し, 主として油浸搪大下 飞観察, 撮影した。

以上の蝸牛殼摘出から撮影迄の諸操作は，常に迅速を 旨として行つたが，他方細心の注意を以つて細胞損傷の 防止以勤ぬ，且つ充分な成果が得られる迄，実験を反覆 施行した。

な叔対照として，摘出組織の固定標本と，断頭及び生

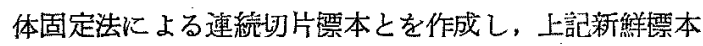
との比較検討の票に供した.

\section{第3 章 観 察所 見}

第 1 節, Corti 器諸細胞の形態と，その微細構造 外毛細胞：生体固定法によるッェロイギン切片摽本 では外毛細胞の位置関係は良く判るが，その内部情造に 就いては，胞体及び核の菱縮が高度なために沿ど窥窅るこ とができない。

新鮮な外毛細胞を1コだけ分離して位顕で観察する と，胞体は肥満円柱状を呈して挌り，核は添ざ球形で， 又聴毛を始め細胞内微細構造物む明膫認められる(第 1 図, 写真 3$).$

即ち，細胞頭部にはや〉透明な 感じを与える 蓋板
第1図 外毛細胞 Deckplatte があり，そこから

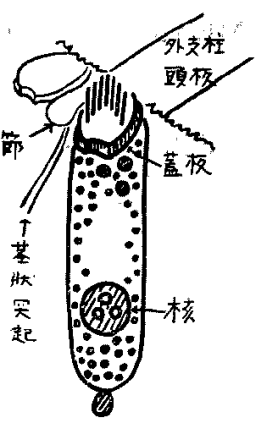
ほ心゙垂值に数本厅至数十本の聴 毛が生えている.

胞体頸部，蓋板直下には，大 小多数の顆粒が密集しており， その大部分はミトニンドリアと 思わわるか゚，中に 1 数個の巨 大な顆粒様物質が存在する.こ 孔が所謂 Hensen 氏小体か否 かル就いては砝認し得なかつ た。

一方，沺胞体中央部では，顆粒が細胞膜周辺にのみ偏 在し，中心部は殆ど均質無構造に見える。

胞体下部には，ほ上゙琲な核が位置しており，その内 部には数個の核小体が認められる。

細部底部は，円錐状をなし，ここには Retzius 小体 があると云われているが，位顕では多数の顆粒集団を認 める。

なお，胞体下端の粒状突起物は殆ど常に発見され，神 経瀻維の終末部と思われる。

次ざに，外毛細胞の頍部を別の角度から観察すると写 真 4 の犃くである． 即ちこれは Corti 器の最内側に位 する外毛細胞の上半部であつて，蓋板の形態が 良く判

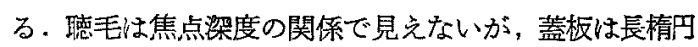
形をなし，その一端て弧状の切痕が見られる。㕛毛細胞 の周辺には，外支柱頭板，ダ氏細胞茥状突起及び節板等 が認められる。

内毛細胞：この細胞もほぶ円柱状をなし，蓋板や㯖 三も喼められ，外毛細胞と酷似した形態を取っている.

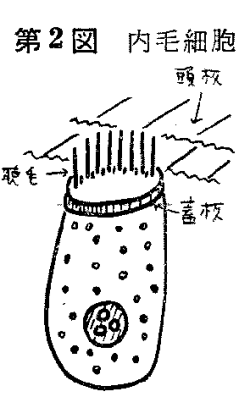

しかしチ細に観察すると，明らか に外毛細胞とは異って拈り，その 第1は，細胞体が短軀で，胞体下 半部がや〉膨大している事である 本細胞の 輸敦は, 普通切片骠本 では殆ど不明であり，新鮮骠本で も細胞膜が薄く容易に変性するた わ，その正礁な像は仲把元難 い, 写真 5 む既に若干の变性膨化 を起している。

第 2 に蓋板が欀棈円形で，外毛細腿に見らタたような 節板の入る切痕が認められない。

第 3 は, 細胞内顆粒の状態で，外毛細胞のような特異 的分布や巨大顆粘は発見されず，大体胞体内炕均等に分 
布している。

第4 の相異点は聴毛であるが，これに就いては後述す る。

ダイテルメ氏細胞：この細胞は写真 $6,7 て ゙ る$ 明らか な如く，おたまじやくしのよらな形をなし，外毛細胞を 抱きかえるように位置しているが，これは1）体部，

2) 茎状突起，3）節 Phalanx の三部分から構成さ礼 ている(第 3 図).

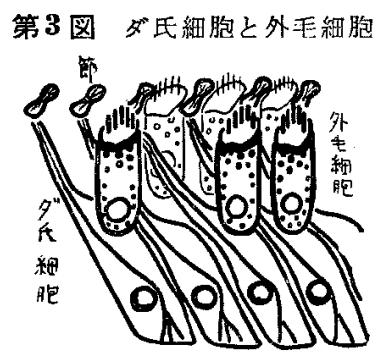

細胞体部は，細胞下端の膨大した部分で，本細胞の主 体をなしており，原形質に富み，中に円形の㚊と多数の 顆粒を含む。

細胞体部上側方には下頭部之乎ばれるや入膨隆した部 分があり，このところで外毛細胞底部を支持している.

細胞体部の上方は，急に細長之なつて茎状突起に移行 しているが，この突起は外毛細胞と同じ長さだけ上方に

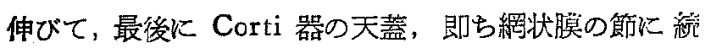
<.

節板は飘単型をなし，隣接ダ氏細胞の節板と交互に結 合して網状を作り，外毛細胞の蓋板を保持している（第 5 因参照).

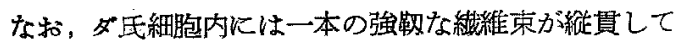
おり，これは基碟膜に接する細胞底から発し，体部，乫 起部を上行して節板に入り，その中で扇状に開いて終つ ている.

ダ氏細胞と外毛細胞との接合関係に就いて検索してみ ると，写真6でる明らかな如く，毛細胞蓋板とが氏細胞 節板とは強固に結合しているが，毛細胞底部とダ氏細胞 下頭部々の結合は極めて粗である。

而も一ケの毛細胞は，たぶ一ケのダ氏細胞によって， その頭部と底部とを支持されているのではなく，毛細胞 頭部を支持するダ氏細胞と，同一毛練胞底部を支へるダ 氏紏胞之は全く別個のるのである．即ちダ氏細胞長軸 は, 毛紐胞長軸化対し上方回転方向に1 数個の細胞間 隔だけ傾斜して括り,このことは毛細胞長軸に一致した
切片骠本で，ダ氏細胞が斜め切りになつていることから も明らかである。

ヘンゼン氏細胞及びタシウデウス氏細胞：へンゼン 氏細胞は，ダ氏細胞に隊接して Corti 器の外側部を形 成しているが，その間に外トンネル腔が介在するため， 新鮮骠本では他部と容易化分離するこ々ができる（写 真 8 ).

細胞体は大型で長卵円形をなし，形筫に富むが顆粒は 比較的乏ぼしい，細胞撙は極めて薄く，且つ細胞閒の結 合が密である，従つて紐胞を一ケだけ分離する事は困難 である。

本細胞に特異的な事は, 細胞内に大小多数の強い粶度 を持つた球状物が存在することで，こ扑は普通切片標本 でけ見ることができず，時炕空胞となつて残存する事る ある。

実跲的に 70\%アルニールを作用させると，比較的容 易に溶解する。又 Sudan 四で褐色に染まる。この事 からこの球状物は脂肪滴と推測される。

脂肪球の分布は上方回転程多く，下方回転程少ない． 又 Corti 器の外側縁の 細胞程, 多く脂肪滴を含えでい、 る.

一方クラウヂウス氏細胞は，蝸牛道外螺旋溝部を被う 五角形の立方上皮で，顆粒に乏ぼしいが形質に富み，甚 た脆弱な細胞で容易に变性变形する。袮は球形で中に数 ケの榕小体を含む。この細胞む又, Hensen 氏細胞と同 じく，若干の脂方滴を持っている。

柱細胞： 柱細胞は，内外2 例の細胞群からなり， Corti 器の主軸をなしているが，その構成は 1) 頭部， 2) 柱部，3）形質部の 3 部からなる.

形筫部は；細胞底部に位し校を持つた形質に富も部分 であるが，極めて脆弱で且つトッネル腔底で基礎脱と接 着しているため,㭷鮮標本では破壊が強く，その詳細な 観祭は困難である。

柱部は S 字状の細長な形態をなし，その下端は三角 形に膨大して直接基碟脱に固着して招り, 又内部には多 数の微細繊維の縱走が認められ，これによって强靬な構 造を維持している (写真9).

内外支柱細胞頭部は中>膨大して互に関節様結合をな しているが，この上をタチタン性の頭板が覆つている (写真 10).

又外柱は内柱上り長く，その基礎膜上に和りる支点 は，外柱が弓状帯にあるのに対し，内柱は非可動性の鼓 室唇先端儿位置している。 


\section{第4図紊栦 細 胞}

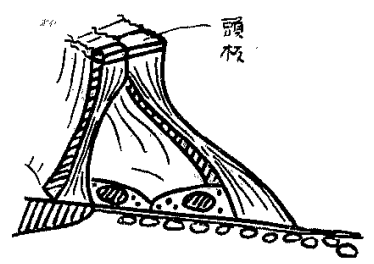

従つて内外 2 列の支柱細胞群によつて形成される三序 形の所謂トンネル腔の上端は，諾干蝸牛軸中心方向に偏 しており，これを新鮮標本で立体的に観察すると，丁度 竹天来のように見える. 又各支柱は密接して並んでいる のではなく，その間に間㩐があつてトンネル腔と又ェル 腔との交通を保つている。

網状膜：Corti 器の上縁は，クデクラ性の網状膜で 被われているが，これを構成するものは，内毛細胞蓋 板，内外支柱頭板外毛細胞蓋板及び ダ氏細胞節板であ る．换言すると頭板及び節板で形成される翰状枠の中 に，毛細胞蓋板が陌入支持された形をとつていら（写 窞 11).

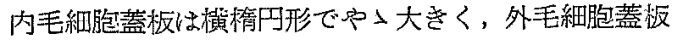

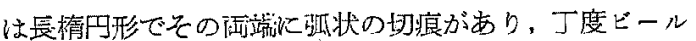
熛のような形をなしている。節板は外毛細胞蓋板の間に

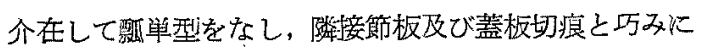
組合さつている。㕛内外交柱頭板は方扸をなして扣り， 外支柱頭板は長方形で大きく，内柱頭板は正方形で小さ W

一般に海狽や家雭では，内毛細胞は1 例、外毛細胞は 3列存在し，これ等は支柱頭板やダ氏細胞節板と共に茯 互の規則的配列を示している。そして蓋板や頭板の大き さには，ある一定の関俰があり，これを特定の帯域に存 在する細胞数から比較すると，次ぎの如くである．即ち

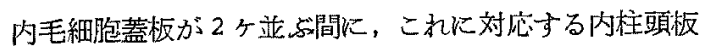
の゙数は，丁度2倍の4ケであり外柱䫑板は3ケ．外毛細胞 蓋板も又3ケである。

第5図 網 状 膜

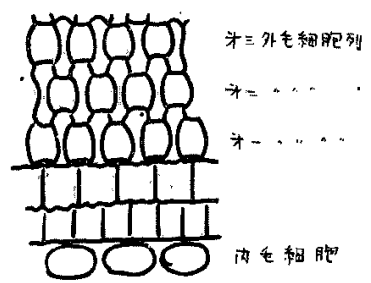

一方位置的関係にる規則性があり，例党ば第 1 列外毛 細胞は，必ず相隣る三つの外柱頭板の中間に位してい 万.

聴毛形態とその分布：位顕の焦点を網状膜から若千 上方に移動させると，感覚細胞の聴毛が浮きでてくる (写真 12).

その際聴毛の発生状態は，各毛細胞に共通な点るある が，その数や形態は，毛細胞の種類及び螖牛回転上にお ける位置によつて，著しく異る。

今説明の都合上，網状膜に打ける外毛細胞の位置関係 を, 内毛細胞側から Hensen 氏細胞側に向つて, 第 1 , 第 2,第 3 外毛細胞之乎称する.

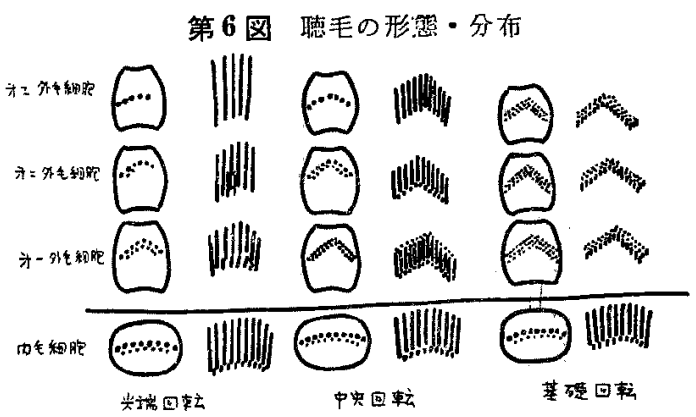

A) 外毛

1)尖端回転：第 1 外毛細胞では，10 数本の長毛が緩 い弧を画いて配列して打り，その長さは約 $6 \mu$ ，太さ 0.1 $\sim 0.2 \mu$ 之実測される. 文, 弧の内側には $2 \sim 3 \mu$ の短毛 が，ほ心゙同数存在するのが認めら机る（写真 13）:

第 2 外毛細胞では，聴毛の数は少くなり10本前後し か数克られず, 短毛の存在も不磪実である。しかし㯖毛 自体は第 1 袖胞の子のより長く, 且つ太くなり, 約 $7 \boldsymbol{\mu}$ の長さを有する。第3 外毛細胞の聴毛法, 6〜8本で最 も少く，㕛長さは約 $8 \sim 10 \mu$ あり，全聴毛中最長であ 万.

2) 中央回轱：尖端回鞋に較べ聴毛の数が急激に增加 し, 反面㯖毛の長さは減退し且つ発毛状態る変てつく る. 即ち第 1 細胞列では，聴毛は二列に並び，その配列 ほ逆 V 宇型で, 数は各列 25 40本, 計 50〜80本と推 測される. 又聴毛の長さは 3〜4 細胞上白短为小（写賣 i4).

第 2 細胞列では，详 U 字型の配列となり，第 1 細胞 列より聴毛は太く，且つ長くなつて数も減少している。

更に第 3 細胞列では，聴毛の配列は弧状となつて，数

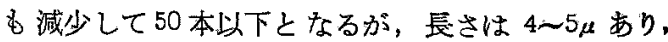


第 1 , 第 2 の細胞のむのより長い..

3）基碟回転：基慗回転になると聴毛は極端に短か く，且つ細くなつて，殆ど点状に見える。㯖毛の長さの

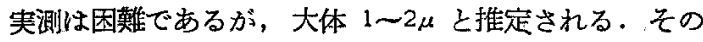
配列徒写真 15 の如く，三列の逆 V 字型をなしており， 数は 100〜150 本数克られる。

一方，この回転では上方回法に見られたような，各細 胞列間に怙ける聴毛形態の差異は余り顕著でなく，目下 の所, 判然とした知見は得ていない。

B) 内 毛

内毛も内毛細胞蓋板からほが直角に発生しているが， その配列状態は写真 16 の吝くで，楕円形蓋板を横断す る緩い弧索画いて招り，こ机等の弧は，外毛と同じく，

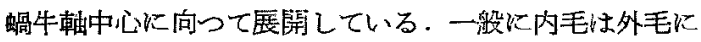
較べ，滛か炕長く，且つ太い，乙かし上下回転別の差は 少なく，その長さは上方回転で $7 \mu$, 下方回転で $6 \mu$ 程 度であり, 数も上方で 20 本, 下方で 30 本と推測され る.

一方，上記聴毛の内側に，こ礼と平行して汪が同数の 2\%前後の短毛が配列しているのが認められた(写真 17)。

第 2 節 蝸牛道を構成する各組織の俯敢所見

基礎膜：基礎暝の横断面を切片標本で見ると，前庭 階被層，繊維層，鼓室階被原の三層からなつている、新

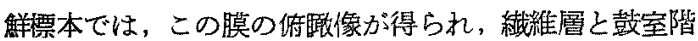
被層とが見られる。

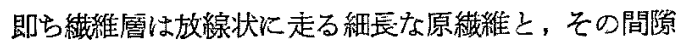
を埋める透明な基質とからなり，全体として强勒な薄䐺 を形成している．この繊集層を透して鼓室階被層の結合 織細胞が見られるが，この細胞は紡程形をなして輸状に 配列して打り，放線状結維とは互に直角に交刃している (写真 18,19 ).

蝸牛全体から見れば，基礎脱、螺旋状の一つの長い带 であるが，その幅即ち放線状䄉維の長さは一定ではな く，私の実測では尖端回転では $200 \mu$ ，基嘫回転では $50 \mu$ 程度である。

ニルテ膜：この胉は前庭唇を基点として, 蝸牛道中

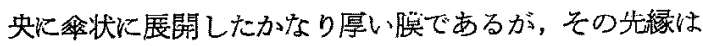
Corti 器の聴毛と接しているものと思われる．新鮮標 本で俯酷すると，放線状に走る多数の繊維と，その間質 とから構成されて括り，膜の下面ほ心゙中央を一本の太い 線が横断している。 即ち Hensen 氏線状と呼ばれるる のである (写真 20).

放線状繊維は一見太い繊維束の上うに見壳るが，仔細

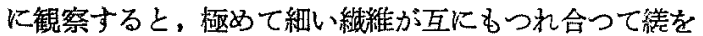
なしたものであり，その走向は，蝸牛上方回転方向に

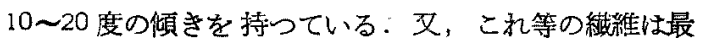

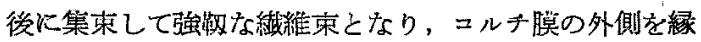

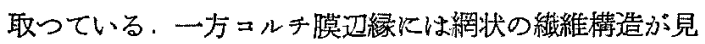
られるが、これとは別に，聼毛之接する膜の下面釉 状柾造が認められる (写真 21).

脈管帯：脈管帯組織を 剶離分離して 新焦標本となす 事は容易である。しかしこの組䋨は，上皮と上皮下との 結合が強固で，薄い標本を作る事が困難である，促つて 位相効果が不充分となり，他の組織の上うな鮮鋭な所見 が得られない，しかしながら，上皮下組織に就いては， その攸瞰像から，多数の血管の蛇行しているのが観察さ れ，且っ赤血㲘の移するのが見られた（写真 22）。

シイスネル氏膜：この膜は，新蟹状態でもかなり広

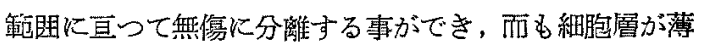
いため，位顕でる相当鮮鋭な像が得られる．即ち，ラ氏 膜は，一層の扁平な上皮性細胞からなり，これ等性涀則 正しい且つ繳密な配列をなしている。細胞形堭は大体五 角形で，中に楕円形の大型な核を含又，形質は汪ざ均質 で顆粒泛どしい，各細胸間の結合は強固で，その間に なえ等の間隔も見当らず，膜自体もかなり強靱である (写真 23).

\section{第 4 章 総括並びに考按}

位顕による膜様迷路の研究は末犬゙少く，僅かに de Vries, 腾木・Corell 等数人の赫告を散見するに過ぎな い, 即ち de Vries (1949 年), Hildung (1951 年)は, ニルテ膜の構造に就いて追求し, 勝不一Covell (1953 年), 山口 (1956 年) は, 海狽蝸牛迷路細胞の新鮮形態 に就いて観察した。私も先きに神岡と共に本研究の一部 を報告したが (1955 年)，これ等の記載を通覧するに，

一概に内耳組織の新焦像之云っても，その記録された細 胞像は必ずしも一様ではなく，形態的にも相当のずれが 認めら机る。このような所見の不統一は，元々微細脆弱 な組織を内耳骨内分ら分離して，生の儘観察しようとす る実㩆方法自体にも難点があるが，その多くは激鮮標本 作成時の組織細胞の損楊已所買死後変化による稩胞变性 とに起因している。

しかしながらこれ等の久楩は，䰝微解剖技術の 熟練 と、実験の反覆施行とによつて，あるいは王死後变化を 逆伯求する事によつて，ある程度防止する 事ができ る。辛，私は本実験において，蝸牛膜样組織を迅速に㒀 出し, 且つ比较的無傷な状態で観察する事がでさたと信 
じている。

一方，同一組織細胞でも新鮮像と固定㧅片像とでは， 著しくその所見を異にする。これは澵鮮標本の持つ特異 的性質に由来するるので，第 1 亿標本が無固定，無染色 であること，第 2 に切片標本では螎牛の縦断面をその主 なる検索面としていたのに対し，新集標本では值接俯瞰 する立場をとつた事。

第 3 亿位影の光学的特性が標本检索上，長短両様の影 響を与兄た率。

等が，その主なる原因である。

そしてこれ等の事は，一面新鮮標本の大きな欠点でも 古るが，反面切片標本では得られない長所でもあり，そ の故に従来兔角等閑視されていたことや，切片標本で确

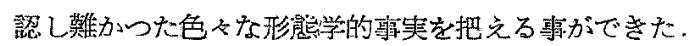

次ぎに，前記観察所見に就いて，先人の記載と照しな がら檢討考察を加えてみる.

第 1 節 観察所見の細胞組織学的検討

感覚細胞に就いて： 外毛細胞が 円柱状をなし，その 頭部に蓋板や眲毛学有する事は, Corti 器の発見当初か ら知られていた。しかし実際に切片標本でこれる見る と，細胞体の萎縮が高度で，その外形は円柱状と云うよ りはむしろ棏状をなしているのが普通である，この 点, 前記䉼鮮標本で得た所見は，先人の記録に比較し て,上り詳細且っ自然に近い形態であると推測される。

蓋板に就いて，Engström は電顕的検索をなし，均 質無搆造なタテリラからなり，その辺緑は楔状をなすと 述べているが，私は，外毛緗胞蓋板が均質透明な棈円板

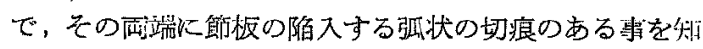
った.

叉, 細胞内顆粒の状態に関し，岩佐は，外毛細胞の㛲 粒が細胞膜周辺にのみ偏在する事を明らかにしたが，斯 かる顆粒分布の特異的状態は, 私の位顕像でも磪認され た.

所で, 1872 年 Hensen は，外毛細胞项部に Hensen 氏小体なるものを発見したが，これに就いて Wittmaack は数ケあるとの見解をとり， Engström は螺旋層 状構造をなすと記載している.私る胞体頸部に数ヶの巨 大影粒状物を認めたが，との実態は把握できず従ってこ れが所謂 Hensen 氏小体であるか否かは断定し得なか つた.

㕛，Retzius は外毛細胞底部に同名の封入体の存在を 記裁しているが，私は特に Retzius 小体と云つた構造 物は発見できず，たよ゙この部に一致して，多数の顆粒等
団を認めたに過ぎない.

一方内毛細胞の形熊に関して，勝示・Covell は球形 をなすと述へ，Eckert-Möbius は細胞下部の球状膨大 を認めている。しかし私の観察知見からすれば，内毛紐 胞は短円柱状であり，玩形あるいは細胞下部の高度の膨 大所見は，むしろ变性に基く二次的形態であると推湖さ れる。

又，前記検索知見から内毛細胞の微細構造を外毛細胞 と比較してみると，次ざの如くである。

1）外形が外毛細胞の長円柱状见対し，短円柱状であ. る.

2) 蓋板は外毛細胞の縱楕円形に対し，横楕円形であ 万、当弧状の切痕は認わられない。

3）聴毛性外毛上り一船に太く長く，且回転別の差 が少ない。

4) 細胞内顆粒の分存に 特異性がなく, 又外毛細胞の. 上う就特㟨な封入体が存在しない。

等である。

以上，感筧細胞に就いて得られた形態学的知見は，就 中内外毛細胞の構造上の差異は，次ぎに述べる㯖毛形態 の特異性々相伴って,内外毛細胞の機能的相異を暗示す る重要な所見と云えるであるう.

聴毛の形態分布に就いて：嵭毛形態に関する知見を 文献的に拾つてみると，古くKolmer は，下等動物の 聴毛は 8 12 本, 高等動物や人間では 100 本以上あると 述べ, Retzius は，その長さを1〜2 弧状の配列をなす事を图示した。

又 1326年 Held は，聴毛の長さが蜩牛部位によつて 異なる事を指摘した．最近勝ホは位顕で㯰毛が逆 V 字 型に生えている事を観察し，山口はこれを逆U 字型と 表見している. 面に Engström や中山は, 電䫓的 3" $\sim 4$ 例の聴毛を記録し，艺の長さが $4 \mu$ で，各聴毛の中 に1本の心のある事を証明した。

しかしながらこれ等の記載は，聴毛の長さ，数，ある いは配列状態等, 報告者によつて皆異つている.

私も偶尺，聴毛の形態関し前記覒察所見を得る事が できたが，それを今総括して述べるならば，次ぎの如く である。

\section{先ず外毛細胞では}

第 $\mathrm{l}$ に，聪毛の長さや太さが，各回転によって，又同， 一回轱でも細胞列によつて異なる事，即ら上方回枟のも の程長く, 且つ太く，下方回転のもの程, 細く短か心， 又外側細胞列程, 長く太くなつている事. 
第 2 K, 聴毛の数は，上方回転程少く，下方回転に行 くに従い增加する. 又同一回転でも外側細胞列程少く， 内側細胞列程多心事.

第3に，これに伴い㯖毛の配列型が，上方回転から下 方回较へと移行するにつれて，弧一逆 U 字一逆 $V$ 宇型

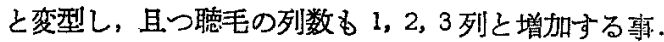
等を知つた。

又, 内毛細胞の聪毛に就いては

1)一般に外毛に比し，著しく太く且つ長い、事。

2）而もその回転別の差は僅少である事.

3）文, 数や配列型も，各回転により大差がない、事. 等を知らた。

更に，一部の外毛細胞や内毛細胞に和いては，上記長 毛の内側比，これと平行して短毛の存在する票を発見し た。

圣, 面白い事に, これ等聴毛の弧状配列は, 内外毛細 盷の体位, 方向関係なく, 総て蝸牛軸中心に向つて開 いている事に気付いた。

以上私の得た所見は，今迄聴毛形態に関し一見統一を 欠くか江見克大前記先人の記载も，局部的には夫之確か な実験記録であつた事を証明して括り，又，聴毛の長さ が蝸牛部位によつて異なると云う Held の指摘が，将に 当を得たるのであつた事を実証している。

斯かる観点から粉合的に判断すると，蝸牛内に展開す る約 3 万の毛細胞は，1ケ 1 ケが各々独自の聴毛形態を 有し，且つこれ等は一定の法則の下整然とした分布を 示していると推測される。

ダイテルス氏細胞

この細胞の形態就いて，山口は梨子状をなすと述 べ,勝木・Covell はフラスコ状と記載している。私は この細胞の微細構造を，体部，突起部，節板の 3 部に分 けて検索したが，その全体の形に就いてはむしろおた まじやくしょうと形容したい。

又, Retzius は細胞内に I本の絒維永を 発見したが， 私も細胞底部から発して 節板に至る 細胞内瀻維を確認 し，これによつてダ氏細胞が保強，強化されている事を 知った。

一方，毛細胞とダ氏胞細との関俰儿就いても追求し， 外毛細胞の交持搆造は，数ヶのダ氏細胞の立体的交錯に よつて作られるむので，このためダ氏細胞虫蟥牛軸方向 のみでなく，上方回転方向にも一定の角度をるつて傾斜 している事を明らがした. そしてこのダ氏細胞の傾斜 㤝，基礎膜の上戒によつて更に高度になるものと考えら
れ,これによつて, 網状膜は, 基碟膜の上下動に刘し, 水平方向の变位をするものと見做される。

ヘンゼン氏細胞

成琶に従光ば,この細胞は Corti 器の䒝持細胞とさ れているが，新鮮時には感覚細胞及びダ氏細胞群との結 合が蒻く，容易に分離される，又細胞膜も脆弱で形質に 富み容易飞变性を起す：この点私は，Hensen 氏紐胞を 支持細胞と 見做す従来の見解には，若干の疑䦓を感ず る。

所で1906年，Wittmaack は，オスミウム酸を使用 して Hensen 氏細胞内に脂肪滴の存在する事を指摘し た. その後 Zytowitch，中村，細谷等が艺の証明を試 み，1921 年下平，万城目はマルキ一氏法で，渡辺，中 道（1922 年）は湅結切片に特いて追求し，最近で性山口 が位顕で詳細な検索を行つている。

その結果，この脂肪滴は，人間や家急にも見られ，特 に海犋に扣いて頙堵であるとされているが，乙かし普通 切片標本では消失して拉り，仲之証明し荼いものであ 子.

私も新焦摽本で, Hensen 氏細胞内に大小多数の強い 輝度を持つた顆粒を発見し，これが脂肪㳸である韧を， アルニール可溶性 Sudam III易染性等から礁認できた。 又，この脂肪滴は Hensen 氏細胞の他伙 Clandius 氏

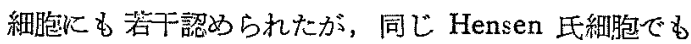
上方回鞋のるの程多く，又 Corti 器の外側寄りの細胞 程多くの脂肪滴を含む事を知つた。

所でこの脂肪澗はいかなる意味を持つるのであうら か，少なくともとの存在は拜視できず，あるいは一船に 単なる支持細胞之見做されている Hensen 氏紐胞の真

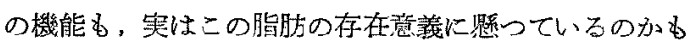
知机ない。

\section{支柱細胞に就いて}

支柱内部老緥走する䋊維群记関して, Held は天の数 を 27 本と記载し，Engström はとの太ざ $0.2 \mu$ と測

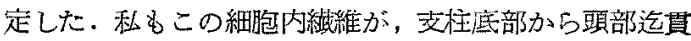
通しているのを钼察し，支柱の保強的役を果している事 を知つた。しかしこの䋘維は支柱底部で終っでりり， 基楚膜との間汇織維の交換は行つていない。このことは 基碟膜から分離された支柱下面の鋭利な断面からも容易 に推測されるが，これは及，强大音響によつて Corti 器 が蝸牛道内に投出されると云ら河田，新井の実験事実か らも明らかな如く，Corti 器と基礎膜との結合の脆弱さ を物語るむのである。 
一方，内外支柱細胞列は，Corti 器の中に所謂トンネ 几腔を形成しているが，その壁，即ち各交柱間仙は一定 の間隚がある。これはトンネル腔と，邓ェル腔との間 に、リンバの交流のある事を示するのである。

又，私は内柱と外柱とがその長さを異にし，而も内柱 の支点が同じ基礎膜でも非可動性の敖空唇上にある事に 気付いた。この事実は既に 1900 年 Ter Kuil によつて 指摘さ机ていたが，音響刺殷に際して起る Corti 器の 動態老教察する上に，見逃す棑のできない重要な搆造上 の知見でるる。

網様膜儿就いて

E:kert Möbiusによれば,“繹状膜は柱細胞碩板と

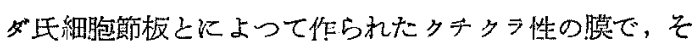
の中に 外毛細胞蓋板の陷入する羭状枠を 形成する”と されている。

このような棰造は，切片像では殆ど観察し得ないが，

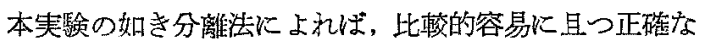
状態を把劣る事ができる，即ち私は，渐鮮標本でその構 造を目繋し，二つの與味ある事契を発見した。

その第1は，外毛細胞蓋板は決して円形でなく，その 两端を酦単形をした節板に喰い込まれ，ビール樽状をな していることである.この事は，従来等䦥視されていた 上うであるが，外毛細胞の揄転を防ぐ巧妙な形態と考光 られる。

第 2 は，支柱頭板及び毛細胞蓋板の結合関係と大きさ とに，一定の規則性のある事である。例党ば，Corti 器 の最内側位する第 1 外毛細胞は, 必ず 2 ケの外柱頍板 の中間に位置して就り，第 2 , 第3 外毛細胞い，これと 交互に同数だけ配列している. 又, 内外交柱細胞の関保 に就いては，Retzius が人問の腸合蝸牛全体で内柱は 5600 r, 外柱は 3800 ケあり。その比は $3: 2$ と述べて いるが，私が海猉の網状膜から得た知見では 4:3であ つて, これ伴い, 内外毛細胞の比も2:3であつた。

即亏内毛: 内柱：外柱：第 1 外毛：第 2 外毛：第 3 外毛 細胞の配列状態は，蝸牛禾端を除けば殆ど挸則的であつ て，細胞数の比は $2: 4: 3: 3: 3: 3$ と見做す事ができる。 基礎暤に就いて

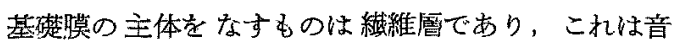
王, 即ちリンパ左変動の感受装置として興味梁い楺造を 有する，新焦摽本で俯酷してみると，均澌なパテ様物啠

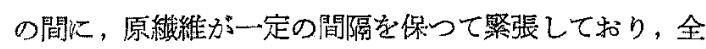
体として螺旋状に展開する薄膜を形成している。この緎

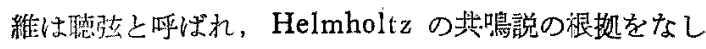

たものであるが, Retzius はその数を 24000 本と数えて いる.

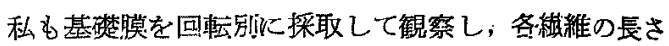
が上方回転程長く，下方回転程短かくなつている事を確 認した。

又，本実験で，聴弦が放線方向に 走つているのに対

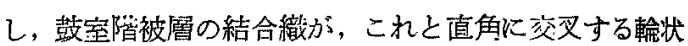
配列をなす事を知つた。

このことは，基碟膜が単なる原綨維の配列ではなく， 膜としての形態をとつている事を現するので，その構造 から見ても Helmholtz の云ら原縝維単独の振動之云ら 事は教光難い。

コルテ膜に就いて

Corti 膜が放線状の䋠䊒構造を持:ち，その中央下面佂 Hensen 氏線条のある事は, Hensen, Retzius の昔か ら知らてていた。 及, Kolmer, Held は Corti 膜の最 外側縁に所謂 Randfaser-Netz の存在することを認め ている.一方 Hardesty は, 豚の Corti 膜豪面炕 accesory tectorial membraneなる䋊状構造のある事を述 べ, de Vries は Corti 膜表面は marginal net で被 れ，これ位影で始めて見出し得るすのと述べている。

私も位顕で，Corti 膜が放維状瀻維とその間質からな り，辺縁に纙状構造のある事や Hensen 氏線条の存在

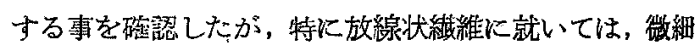
原纎維が撚れて箱束したものであることや，それが上方 回転方向に 10 20 度の角度を以つて走つている事等を 知つた。

所で Corti 膜で最も問題にされていることは，Corti 器との関俰である。即ち Corti 膜と聴毛とは

1) 全く離断している

2) 単に接触している (de Vries, Mygind)

3) 接着している (Kolmer, Held, Hardesty)

4) 結合している (Schambau, Prentis, Wittmaack, Hildung）のいずれの状態尼あるのか，と云う事であ る、一般的には音刺战時のみに接触すると見做されてい るが，形態学者の大部分は，接着若しくは結合があると の見舴を示している.特隹 Schambau や Wittmaack Held は, Hensen 氏線条を以つて, 境界細胞 (Gretz Zellen）と附着すると侾えている。

私もこの閣題化就き，落干の检索を行つてみたかか結論 は得られなかつた。しかし，1）切片標本ではCarti 膜 と聴毛とが接触している場合が多い事，2）しか心新

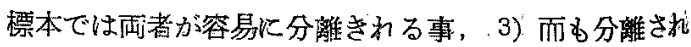


たCorti 䐉には，聪毛の附着，殘存がない事等から， 私は，Corti 膜と㯖毛とは，生体時には接着している が，しかし Wittmaack の云う吝き畒固な結合はない ものと考学る。

脈管带に就いて

脈管帯は機能的に見て，内リンパ液の成生分汹に関保 寸る場所として，Guild, Schambau, W:ttmaack 等に よつて多年演争されてきた所で策るが，形態的に見て む，多数の終末血管の存在寸る事户，上皮細胞の特殊性 等から注目されている組織である、しかしながら新然標 本では租織自体が厚く剝離されるため，上皮細胞に就い ては充分な検索をなし得ず，僅か炕終末血管の走行の観 察に留った。

これに関連して L. Katz（1891）の梳文が想起され る. 即ち彼は，脈管帯上皮細胞忙 besen börmigなる ので, 基底に向つて多数の原形質突起を出す事を明らか にしたが，最近中山も電顕でこの事起据証している。こ

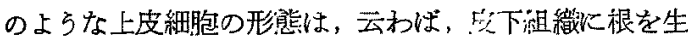
やしているようなるので，このために本実験でる上皮圓 全体が厚く剝れたのかる知机ない，

ライススネ氏膜に就いて

Retziusによれば, Reissner 償は一管の内皮系細 胞と一層の䊉緟形をした上皮とから成ると云和れ，我々 る切片標本で容易にその横断面を钼察し得る. しかし， この膜の俯瞰像に就いては，従来余り記載されておら す゚，僅か灿山の報告を見るのみである。

私は，この実験で，ラ氏膜が中央に大型の棈円形秋を 有する五角形の扁平な上皮細胞からなる事を知つた。气 してその配列は一曆に過ざないが，かなり維贸なるの で，細胞間火は何等の間隐形成も見られなからた。この ことは，ラ氏膜が内外りンバ液の芫全な隔壁として働、 ていることを示するのである。しかし，この膜が結締織 性でなく上皮性からなる事は，ラ氏膜が単なる隔壁とし て存在するのでなく，そのところには内外りンパ液の湠 透，透過阅関連した何等かの機能を有する事を示崚して いる.

第 2 節 Corti 器の構造と，その音䬶刺晫による 変位に就いて

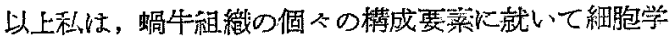
的立場から考察を加完てきたが，次ぎにこ机等の知見を 総括して, Corti 器の構造を音響感受装置と云う江場か ら検討してみる。

Corti 器は感覚細胞と支持細胞とからなる上皮系䗝織
ではあるが，その形態愫造は甚だ特異的で，多分に機峨 的な要意を持つている. その特徵を列記すると，

第 1 は, Corti 器の交持装置縤維系の存在であり，第 2 は感覚細胞の支持構造である。第 3 亿内外交柱の形管 之位置，第 4 にコルテ膜と関連した㯖毛形態の特異性等 が挙げられる。

第iの支持織維系に就いては, Helả が

1) Allgemeine Tragbogen

2) Basal Stützen dieses Tragbogens

3) Basal besondere Stützen der Haarzellen の3ロ分類している.

1）は，内柱，最外側氐緗胞及び網状膜によつて形

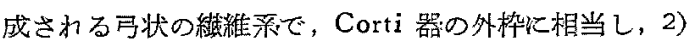
は，外柱及びダ氏細胞による Corti 器の内部保强瀻維 で，3）泣，ダ氏細胞側頭部に分枝した外毛細胞の支持 䋊維である。

私も前記実験に括いて，内外考柱，ダ氏細胞及び網状 膜等の微細構造を追求し，Corti 器の独特な形態を維持 するものが，これ等細胞内瀻維やクテクラ性膜である事 を知つた，そして Corti 器の支持䄉維秃に関し，第.3 の項を除き Held の考え方に全く同調するものである. 殊に新鮮状態で見る Corti 器の細胞は甚だ蟣弱なるの

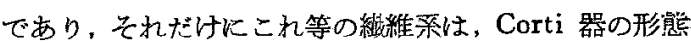
維持に重要な役をなするのと思われるが，更にこれ等の 結䊒は Corti 器に弾力を与光，且つ音圧による Corti 器の変形を速か復元させる原動办になつているとる考 壳られる。

Corti 器の構造上，興味ある第 2 の点は，感覚細胞の 支持装置である。こ礼化就いて Held は縤維系の支持 構造を考えているが，私の前記知見を総合すると次ぎの 上らになる。即ち，毛細胞頭部は蓋板を以つて網状膜の 中に陷入しているが，そのところには強固な結合はな く，蓋板の一端を以つてダ氏細胞節板と結合しているに 過ぎず，蓋板の蝶番㥆運動を可能にしている，又，毛細 胞底部は，ダ氏細狍下部に支えられているが，その間の 結合は弱い，而も同一毛細胞の䌿部之底部を支克るダ氏 細胞は，全く別個のものである。一方細胞体壁は噒接細

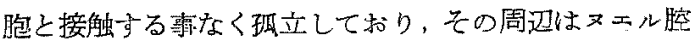
となつてリンバが満されている。か人る毛紐胞の支持構 造恃，感觉細胞の可㢦性を推察させるものであるが，乙 かしその捻転は，蓋板の弧状切痕によつて巧妙儿防止さ れている. 叉，若しトンネル腔のリンパに何等かの变動 が起れば、その影㗽は直ちにヌェル腔のリンバを介して 
直接毛細胞に働き，毛細胞自体の運動あるいは圧縮を薏 起するとも考える.

Corti 器の第 3 の特徴忧, 内外支柱の形態之基礎膜上 に拉ける位置である。即ら外柱が長く内柱が短い事, 又 これによつて Corti 器が半卵円形をなしている事は, 唯れでも知っている。しかとの理由に就いては詳らか でない，又，外柱の菆点は，基礎膜の最も可動性に富む

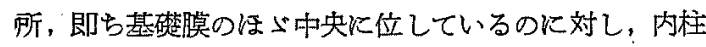
支点は非可動性の鼓室唇上にある，從つて基礎膜の振動 《よつて起る内外支柱頭部の変位は, 単純な上下運動で 恃なく，内柱底部を支点として内支柱を半径とする円周 上の運動を示すことになる。

第 4 の特徵は，Corti 膜と関遉した聴毛形態の特異性 であるがこれれ就いては前述した。

以上の諸点から見て, 私は Corti 器を単なる一塊の 上皮組譈とは思わず，もしろ音響感受のために作られた 巧妙な機珹之考克度い.

しからば，Corti 器恃音響刺㦸に遭遇した際，いかな る変動を示し，いかなる機序に扎いて音を感受するるの であららか。

一般的には，基碟膜の上下動が值らに Corti 器の上 下動を促し，その際聴毛がコルタ膜との関連において圧 迫刺战されると見做されている。しかし1900年 Terkuil は，内支柱の底部が非可動性である事に注目し，Corti 器は基礎膜の上昇によつて螖牛内方に移甥すると推定し た. 更に 1950 年 Neubert は，Csrti 器の聴覚機構に 就いて形態学的立埸加ら考察を加克，蝸牛外リンパに伝 光られた音圧は，結局蚎牛内螺旋满内のリンパ压を高

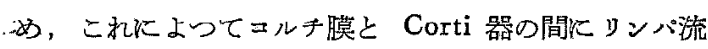
林生ずるとし，こつに怙いて始めて缌毛が刺践されるも のと考えた. 又, Hildung は“眲毛は Corti 膜と接着 している”との見解の下に，聴毛の被刺㦸時の状態に “就いて検討し，基礎膜の振動你祭して，聴毛の先端即ち コルチ膜附着側は前庭唇を中心にして半円を画き，恥毛 の根部即ち Corti 器側は鼓室唇を中心に半円を画くと 想定したそそしてその半径の実測値から，基碟膜が上戒 した際には，聴毛は圧迫ではなく逆索引伸長されるる のと推測した。

斯くの如く，形態学的見地から聴覚機構を考光る時, 一音波によつて若起されるCorti 器の变動は, 単なる上 下振動ではなく，もつと複雑なものであり，従つて聴毛 の刺战される機序に就いても再考の要があると思われ .る.そこで私も，前述の形態学的知見に基いて，音刺踣
に際して起る Corti 器の動態に就いてーつの想定を下 してみる(第7,8図参照).

第 7 図 慗刺践時のCorti 器

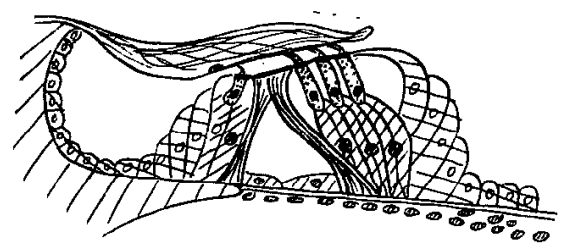

第 8 図 諳刺故によるCorti 器の 変位と液の移的

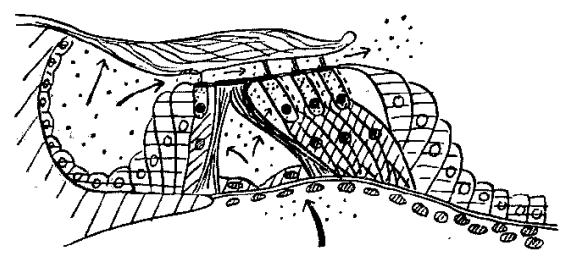

基礎膜が振動する際，その振幅の最大の部位は，形態 学的炕見て最も可变性に䈏孔外支柱の附着部之考えられ る. 従つて基碟膜の上戒によつて，外支柱は上方化上 げられるが，その際内柱底部は鼓室唇上にあつて不変で あるので，内外支柱頭部は必然的に蝸牛内方に移動与 る.これによつてトンネル腔内は狭小となり，その夜玨 は昂進するが，一部は支柱間吵を通つて メェル腔に達 し，毛細胞体壁を直接圧迫して感覚細胞を厉起状態㯰 $<$.

又, ダ氏細胞む螖牛軸並びに上方回転方向に一定の角 度をむつて傾斜しているので，基碟膜の上昇によつて絧 状膜が上方に移動する事は少なく，むしろ Corti 器恃 全体として扁平化し，内螺旋清に向つて变形膨出する. その結果, 内螺旋溝は狭小となり, 該部のリンパ圧の上 界をきたすそしてその压の一部は，蝸牛螺旋に沿つて 上下回転方向に逃れるがなお一部はコルチ膜を上方に 押し上げ，頁に一部は Corti 器とコルチ膜の間を通つ て内ッンパ腔外方に向う.

所で無刺㦸時，換言すれば定位置にある時は，Corti

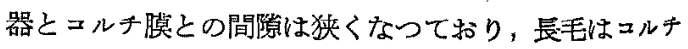

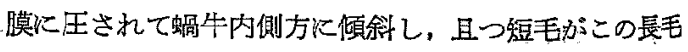
と交叉して，長毛の運動を阻止していると考觉られる。 しかし私は先きに、聴毛とコルチ膜との間に強固な結合 はないが，接着あるすのと見做したが，この見解化従兄 ば，基礎膜の上年によつて起る網状膜の内方移動とニル 
テ膜の上年とは，聴毛を垂直以立毛させ，且長毛と短 毛とを並行にさせて、その交叉を解く結果になる。こ〉 に和いて德毛は始めて被可動性の状態となり，内螺旋满 からの液王の変動に対して反応同調を示し, その剌韩を 蓋板を通して細胞内部に伝達するるのと考えられる。

斯く考えてみると，各感覚細胞の聴毛が蝸牛軸方向に 向つて弧状の配列を示す事は，液圧感受に取つて誠に好 都合な形態と云わねばならない。

第3 節 聴毛形態と周波数分析能に就いて

本侀究で私は，聴毛の長さ，太さ，数，配列が，毛細 胞の種類や蛊牛螺旋上における位㽞によつて，著しく異 なる事を知り，而もその間に一定の規則性のある事を発 見した。そしてこの事に就いては，既に第59回の耳奥

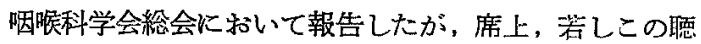
毛の状態を，適当な印なり記号で螖牛螺旋上に画いてゆ くならばそそのところに一つの地図ができ上るものと思 いこれを Culler の螖牛地図に做い，聴毛地図と呼ぶ 事を提唱した。

所で, 今仮りに, 前述の聴毛の状態を, 全回転に亘つ て模式化してみると, 第9図の如くなる.そしてこの図 から私は, ある稬弦楽器の弦を連想し, その棈造に就い て験べてみた。即ちグランドピアノの胘は

1) 低音程長く太く，高音程短かく細い。

2) 低音部は 1 本弦, 中音部は 2 本留, 高音部は 3 本 故である。

3）高音部の一部を除き，各热に Dampfer と称する 抑音装置が附いている。

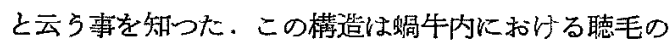
状態と極めて良く類似して特り，特にピアノの弦が，音 高によつて 1，2，3本弦となつている鼓は，聴毛の配列 が蝸牛回転によつて 1，2，3列をなす事と一致し，又ピ アノに附いている抑音装置は，一部の毛細胞に見られた 短毛の存在と対比させる事がでさる（第6图参脰）。

而してビアノの各弦は，各々が固有振動数を持つた僈 秀な 発音体であり，若しその抑音荘置を開放するなら ば，逆に共鳴弦として働き，固有振動数に一致した音響 に対し共振共鳴を起す

斯かる観点に立つて㯖毛の形態分布を見るならば， 我々はこれを弦楽器の慈に例克，各聴毛は槊なる刺㦸伝 達の中介者ではなく，承つと積極的に各種旁在を分析感 受する所の一種の共鳴昡であると見做す鹃ができないで あろらか。

しかしながら聴器の周波数分析能に関しては, 古くか
ら稉々猃議され，これに就いては多くの仮説が生れていい るが，未だ鱾毛に分析能を持たせて説いた子のは見当ら ない，そこで先ず，今日迄に考えられてきた㙏覚理桷の， 中，主なるものを拾つてみる。

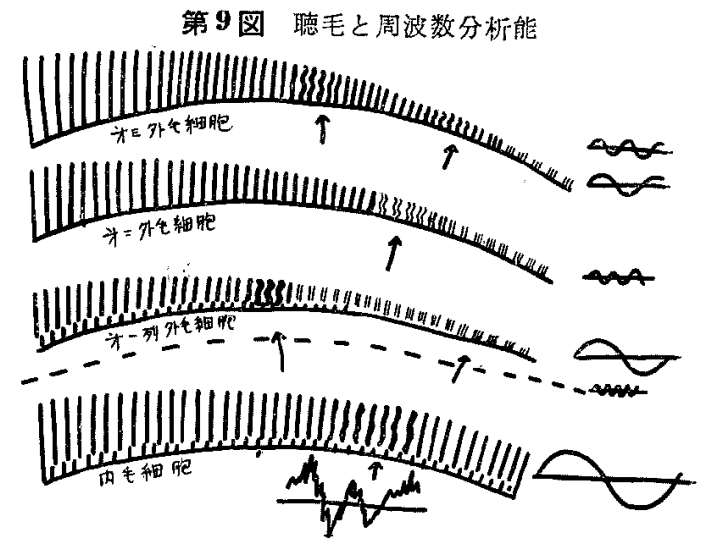

その第1は Helmholtz の共陮説であるが，彼は基

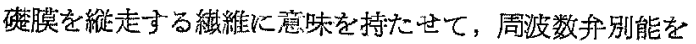
説明した。これは極かて卓越した理論であるが, 形態学: 的にも生理学的に飞若干の根本的疑点交残している。

これに対し Ewaldは，定常波による音像説を立て， Békésy は，進行波による洞流の生成を意味つけた。又. Wittmaack は、ニルチ膜とニルテ器を完全に結合した 一つ器管と見做し, 所謂 Turgeszenz effekt で理解 しよらとした。

一方, Wever-bray は, 音刺㦸に際して起る螖牛及び 楒神経内の電気的変動を証明し, Culler は, 螖牛電気, 現象から，音高感受部位分布を，蝸牛地図として現わっ

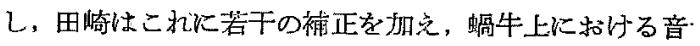
高感受の局在性を実証した. 又 Galambos \& Davisは，

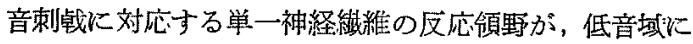
広い幅を持つている事を証明し，Fletcher はこれ等電 気生理学的実験成續加ら, Space time pattern theorie なる考えを出した，更に最近，勝木は絲皮質の锶領野に 拈ける音高感受部位の分布状態に就いて追求し，周波数 分析に関し螖牛より高次の場所を推定している.

しかしこれ等㯖覚理誦の大部分のものは，基整膜全体 の振動から周没数金別能を考㝋たものであつて，複合音 の分析能や，位相的影響の説明に整点があり，上記諸説 を以つてしてす音感覚の色なな現象を充分に理解するこ

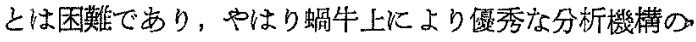
存在する事が照ましい。 
そこで私は本桷文の最後に，前記解剖学的知見を統括 して，内耳の音高弁别機擭に就いて，一つの推測を下し ててみたい。

鐙骨を介して前庭階に伝えられた音波は，一つには蝸 牛孔を経て裁室偝に遵するとも云われ，あるいは Bék-

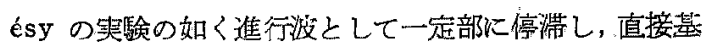
碟䐺を振動させるとも云われている。しかしいずれにせ よ基礎膜を振動させる事仙変りはなく、ここに基礎膜に 郝ける音高感受の局在が問题となる。

これと就いては, 既沉 Helmholtz, Ewald, Békésy 等の生理学的実駼があり, Fletcher, Zwislocki 等の数 学的証明もある. 又吉井, Wittmaack は, 過大音響缡 䟠を与えて，組織病変の発現部位が周波数によつて異な る事を病理学的実証している。

そしてこれ等の䃑究は，その成績に若干の差はあつて も，基磷膜上に扔ける音高感受の局在性と云う点では皆 共通であり，私も形戀学的立暘からこれに同調する者で ある、しかし、そこには Helmholtz の説えるような意 味の局在は無く，その振勤带域はもつ之広範なものであ つて，且つ幾つかの相接近した周没数を有する複合音に

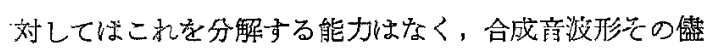
・の形で振動するものと考えたい。

次いでこの基礎膜の振動は, 一つにはトンネル腔, ヌ エル腔のリンパを介して，直接毛細胞体壁を刺㦸して感 覚細胞の厉起状態をむたらし，一つには Certi 器を介 して螪牛内螺旋溝内のリンパに伝達され，その液圧が Corti 器とニルテ膜との間嚐を通過する際, 恥毛を振動 さ过る。この際, 内螺旋溝内の液圧は，基礎膜と同じ合 珹音没形の变動字示するの之見做されるが，こ〉で恥毛 の形態分布が，周波数弁别並びに複合音の分析に結び付 き, 重要な意味をを持つてくる。

若し，各聴毛の形態が，音響物理学的条件江合致して いるものとすれば，尖ふの嵭毛以特定の固有振動数を持 つ事になり，内螺旋溝からの液圧に対し撰択的烘振を 起するのと考党られる。

即ち，内毛は全回転炡つて唇く太い，従つて内毛細 胞は，螖牛全域に和いて，比輘的低音に共振する。一方 外毛は，回転別により，又細胞列別によつて長短の差が 著しい，従つて外毛細胞では，低音から高音迄，各周波 数に応じて共振し，その蝸牛上に扣ける感受部位は，聶 毛形態力ら低音は上方回転，高音は下方回転と限局され る。

換言すると，低音は蝸牛全域に亘つて感受され，それ
以上の周活数の音は, 螖牛回転に従つて局部的に感受さ れる。

この事は, Culler, 田崎の Microphonics とよる Tone Localisation 関する实駼成果と，ほぶ一致す るが，乙からば，何故外毛細胞が全音域に共鳴するのに 対し，全毛細㴔は低音のみを感受するのであろうか， 又，何故，内毛細胞は 1 列で, 外毛細胞は 3 列 (人間で は3〜5列あると云わ机る）存在するのであろらか？

これに就いては，各毛細胞を夫ミ独立した芙鳴器の配 列と見做し，こ扎 Ohm の法测を適合させて，復合 音の分析と云う見地に立つて考えてみると，容易代その 理由を説明することができる。

即ち，活音の易合は勿論闘题ないとして，合音（複合 音)の昜合、先ずその基望 (原音)を感受するものは内 毛細胞であり，更にその上音を幾つかの段階に分けて撰 択的に共振分析するすのは, 各列の外毛細胞である（第 9 図参照).

とす机ば，内外毛細胞及び聴毛の配列は，『缌覚は，単 弦振動のみを純音として感じ，有らゆる音響（合音）を ば，その分音 (純音) と分解して感ずる. 而してその綜 合として当該音響が烟賞される』と云う Ohm の法测

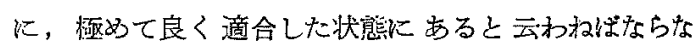
w.

而してこれ等の聴毛が，内リンパ液の強制振動によつ て共脤させられるもの之すれ标，特定の固有振動数を有 する聼毛の外に，その周辺に存在する毛細胞の聴毛すす る程度振動を強制される，そしてその各細胞における聼 毛の共振に上つて生ずるェネルギーの総和が，即ち，音 の強さ，刺钱の強さとならて神経に伝えられるるつと考 点度い。

以上述べてきた事は，実験的に知り得た解剖学的知 見から推察される聴筧機序に 対する一つの解积であつ て，何等生理学的な实験根拠はない，而かもそこには幾 つかの仮定が挿入されて扣り，私は必ずしもこの仮説 に固執拘泥寸るものではない、しかしながら，このよ 5に考光る事仗よつて，一つには今迄疑問視されてい た㯖覚生理学上の諸閣題を, 特に高度の周波数弁別能, あるいは合音の分析機序と云う事を容易に説明できる し，又一つには，従来鬼角説明困難であつた。あるいは

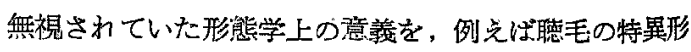
態, 内外毛紐胞の区则，内螺旋溝，トンネル腔等の存在 理由等々に対し，比較的楽に意味付ける事ができる。 又, 近年急速に進歩した電気生理学的実験成果と比䡬し 
ても，特に本貿的な矛盾は認められない，殊に，音刺战 に対応する單一神経能維の反応領野が，低音域に広い幅 を持っていると云う Galambos \& Davis の仕事は, 各細胞が夫心周波数分析能を持つとする私の主張上，一 見相区するかの如く見光るが，この矛盾も，外毛細胞に 行く聴神経䋊維の走行が，上方回䩪方向《迁回しながら 分枝すると云う Lorente de No の組織学的見解之対 比して考えるならば, 容易に解決される.

そしてこれ等の事は，上述の仮説が根本的な間違を犯 していないことを示江するものと信ずるが，しかしその

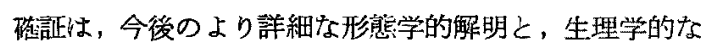
実験成果とに待たねね゙ならない

たよ゙，螖牛組繳，特に Corti 器の 形熱をこのように 考克る事によつて, 從来の聴覚理論が基礎膜住主体を置 き, あるいは神経繊維の電気的追求に専念していたのに 対し, 新らためて Corti 器の重要性を強調し, 例え1 本の纎維の走行, あるいは1ヶの細胞の位置, 形態に も、聴覚機構上見逃すことのできない意林:のある事を主 張するるのである.

\section{第 5 章 結 論}

位相差顕政鏡を応用して, 海犋の新鮮䛿牛膜㥞迷路に 就いて, 組淁細胞学的な检索を行い，その所見を固定切 片標本像と比較検訂した．その結果

1) Corti 器の感筧細胞及び支持細胞を単独分離して, その福鮮時就ける状態を観察記録できた。

2) Corti 器を構成する各細胞間の位置的形態的関俰 を追求し, Corti 器の特異的構造に就いて, 装干の知見 が得られた。

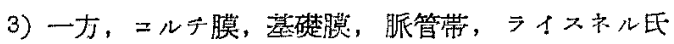
膜に就いてむ検索を加え，その螺旋膜㨾構造を明らかに した.

4）特に聴毛に就いては，感覚細胞を蝸牛回転別に採 取して検索を加え，煖毛の形態分布が毛細胞の程類及び 蝸牛螺旋上に拈ける位置によつて著しく異なり，且つそ の間比一定の規則性のある事を指摘した。

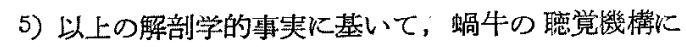
対して考察を試み，聴毛が周没数分析機能々密接な関係 にあるとの推测を附記した。

\section{文献}

1) Bast, Eyster: Ann. Otol., 44, 792, 1935. 2) Bennet, Osterberg etc.: John Wily \& Sons, Newyork, 1951. 3) Bethes: Handbuch der Normalen und Pathologischen Physiology Bd II, 497, 1926.
4) Burlet: Handbuch d. Vergleich. Anatomie d. Wirbeltiere Bd II. 2Hälfte, 1293, 1934. 5) Culler: Ann. Otol., 44, 807, $1935 . \quad$ 6) Davis, Lurie, Steverns: Ann. Otol, 44, 777, 1935. 7) Deilers: Untersuchungen über die Lamina spiralis membranacea. Henry et Cohen, Bonn, $1860 . \quad$ 8) Denker. Kahler: Handb. der Hals usw Heilk., Bd 6, 1926. 9) Engström, Wersäll: Acta Oto.Laryng. 43, 1, 32, 1953. 10) Ewald: Pfüger Archiv, Bd. 76. 147, 1899. 11) Flecher: Speech and Hearing in Communication, $1929 . \quad 12)$ Galambos, Davis: J. Neurophysiol., 6, 38, 1943. 13) Gui'd: Americ. J. Anatom. 39, 57, 1927. 14) Hal'pike, RawdonSmith: Ann. Olol., 46, 976, 1937. 15) Hallpike: Acta Otol., 26, 145.1938. 16) Hardesty: Am. J. Anat., 18, 1, 1915. 17) $\mathrm{He}^{\prime} d$ : Untersuchungen über den feineren Bau des Ohrlabyrinth der Wirbeltiere, Bd. I. Leipzig, 1902. Bd. II, Leipzig, 1909. 18) He'd: Zeitschr. f. H.N-Ohren Heilk,, 9, 279 , 1924. 19) He'd, Kleinknecht: Pflüger Archiv d. ges. physiol., 216, 1, 1927 . 20) Helmho'tz: Die Lehre von den Tonemptindungen, Frieder, Vieweg \& Sohn, 1913. 21) Henke, Lubxrsch: Handb. der speziellen Pathologischen Anatomie und Histolog. ie, Bd XII, Berlin, 1926. 22) Hensen: Arch. f. Ohrenheilk., VI, 1873. 23) Hildung: Ann. OtoRhino-Laryngo., 61, 355, 1952.24) 細谷: 久保全 掏, 第 2 巻, 192, 1942. 25) Hughson: Ann. OtoRhino-Laryngo, 44, 777, 1935 . 26) Iwasa: Folio Anat. Japon., 3, 313, $1925 . \quad 27)$ Katsuki, Covell:

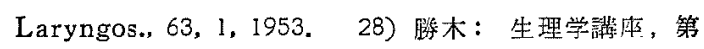
10 巻, 1. 29) Katz: Arch. f. Ohrenheilk., 31, 66,1891 . 30) 切替: 日耳鼻全書, 第 1 巻, 第 1 冊, 1, 1953. 31）切替：日耳鼻会報，60巻，1786，1957. 32) Kolmer: Handb. der Neurologie des Ohres (Alexander, Marburg), Bd. I, 1924. 33) Kolmer: Arch. f. Mikro. Anat., Bd 70, 1907. 34) Kolmer: Anat. Anzeig., 36, 281, 1910. 35) Lorente de No: Laryngos., 47, 373, 1937. 36) Lurie: Laryngos., $47,418,1937.37)$ 水平：位相差顆微鏡と飞の応用， 医学费院, 1952. 38) Mygind: Acta Otol., 35, 108，1947。39）中道: 大日耳鼻会報，汭巻，355, 1920.40) 中村：大日耳奥会報，41 尞，4,5, 7 号, 
1935. 41) Neubert: Zeitschr. Anat., 114, 539, 1950. 42) 恩地：耳咽, 24 巻, 13 号, 1952. 43) Prentis: Am. J. Anat., 14, 425, 1913. 44) Retzi. us: Das Gehörorgan der Wirbeltiere Bd. I. II, Stockholm, 1926. 45) Stevens, Davis: Hearing, John Wily \& Sons, 428, $1938 . \quad 46)$ Stevens: Recent Advances in Oto-laryngo, 84, 1949. 47) Tasaki: J. Neurophysiol., 15, 1952. 48) Ter Kuil: Pflüger Arch. g. Physiol., 79, 149, 1900. 49) 富 田：生理学紫幽，第 10 巻， 1，3. 50) Tsuiki, Watanave, Kamioka: Tohoku J. of Exper. Med., 62, 137, 1955. 51) 立木, 渡辺：日耳舆会報，58 巻,臨 時号, 150, 1955. 52) de Vries: Acta Otol., 37, 334, 1949.53) 渡辺：大日耳舆会報，26 巻，349, 1920. 54）渡辺：大日耳獣会報，28 尞，273, 1921 . 55) Wever, Bray, Horton: Ann. Oto-rhino-laryngol., 44, 772, 1935. 56) Wittmaack: Zeitschr.f. Ohrenheilk., 51, 148, 1906. 57) Wittmaack: Zeit- schr. f. Ohaenheilk., 54, 37, 1907. 58) Wittmaack: Arch. f. O-N-Kehlkopfkrankheit, 115, $1926 . \quad$ 59) Wiltmaack; Acta Otolaryngol.' 24, 397, 1936. 60) 山口：日耳县会報, 59 巻, 1 号, 1956. 61) Yoshiz: Zeitschr. f. Ohrenheilk., 58, 201, 1909. 62) 湯浅: 細胞学, 同文館, 1942. 63) Zwislocki: Acta Otolaryng. suppl., 72, 1943. 64) Zollinger: Am. J, Pathol. 24. 545, 569, 1948.

稿を終るに臨み，終始御暿篤なる御指導，御 校閲を賜つた恩師立木教授に゙対し，深甚なる謝 意を表します。

又, 种岡葆二博士の御指摰と中山和彦，鈴木 孚両氏の御協力に梁謝致します。

（原穆到着 $=$ 昭秃 34.4 .24 日） 


\section{渡辺論交付図（I)}

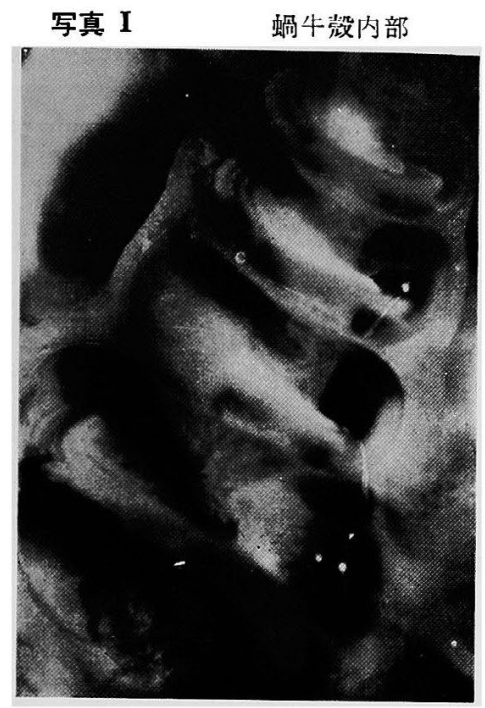

写真 3 外毛細胞 (位顯) (1500 ×2 倍 $)$

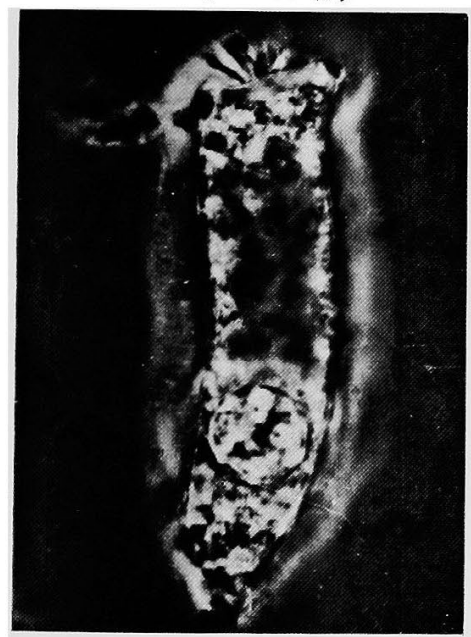

写真 5 内毛細胞 $(1500 \times 2$ 倍)

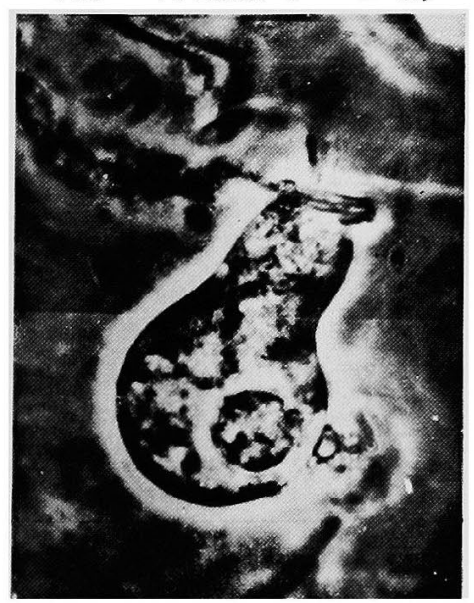

写真 2 Corti 器 (切片標本)

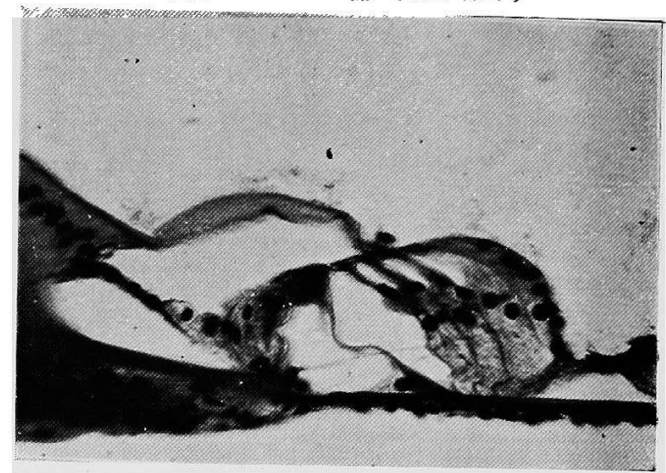

写真 4 外毛細胞頭部と外栍頭板 (1500 ×2 倍)

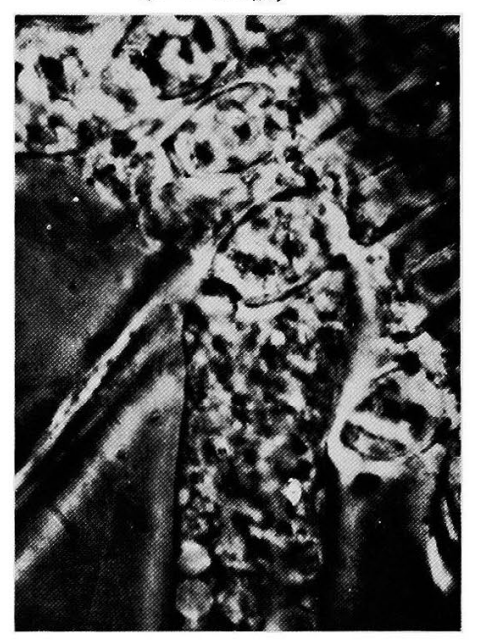

写真 6 外毛細胞とダ氏細胞 $(800 \times 2$ 倍 $)$

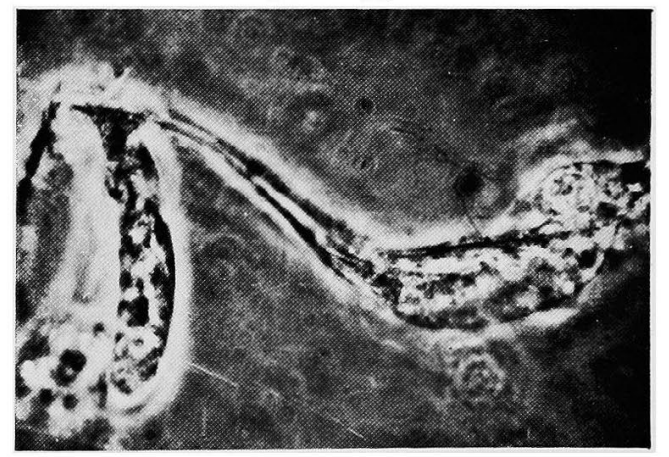


写真 7 ダイテルス氏細胞（1500×2哗）

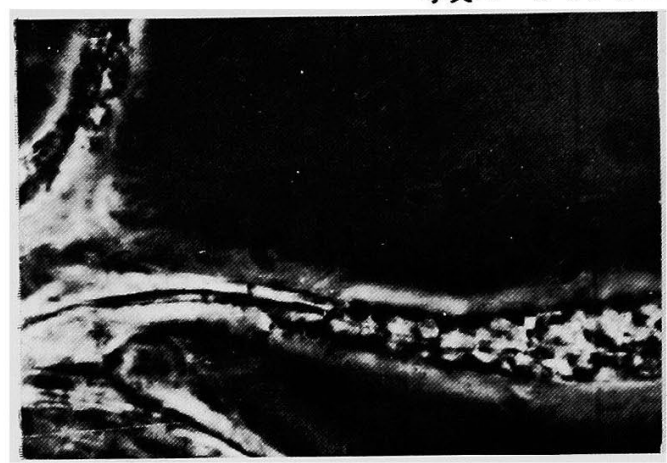

写真 8 ヘンゼン氏細胞 (1500×2(倍)

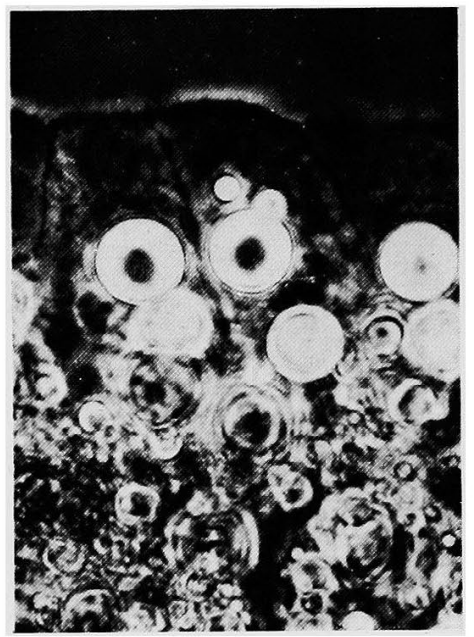

写真 10 内外支任細胞頭板 (1500×2倍)

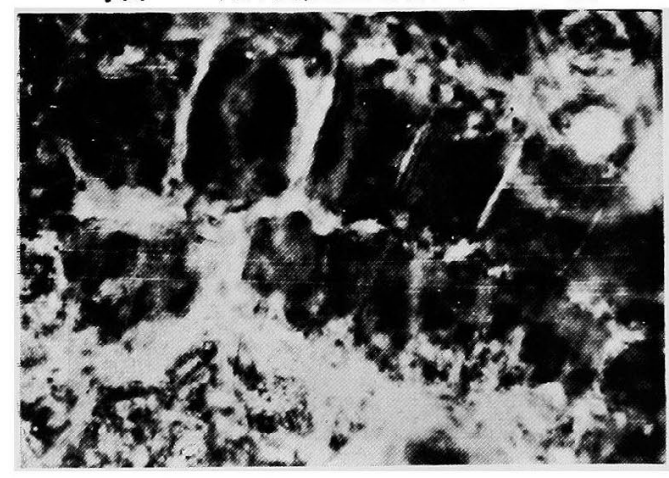

写真 9 外支 杜 底 部 (1500 2 倍)

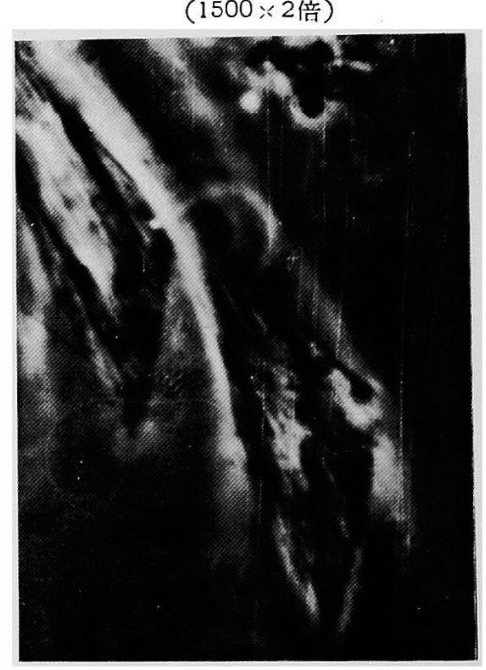

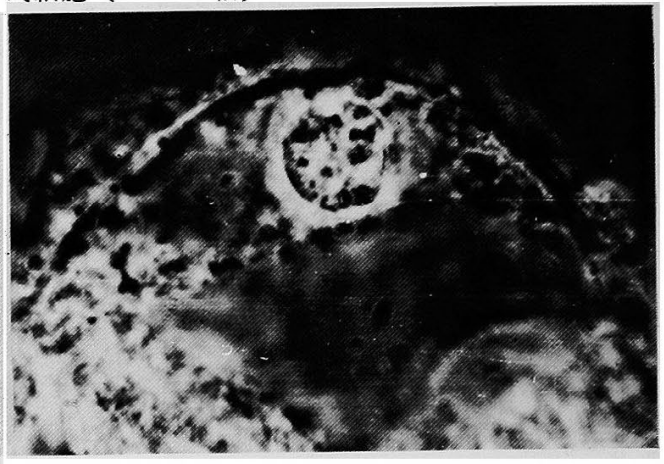

写真 11 網 状 膜 $(800$ «2)

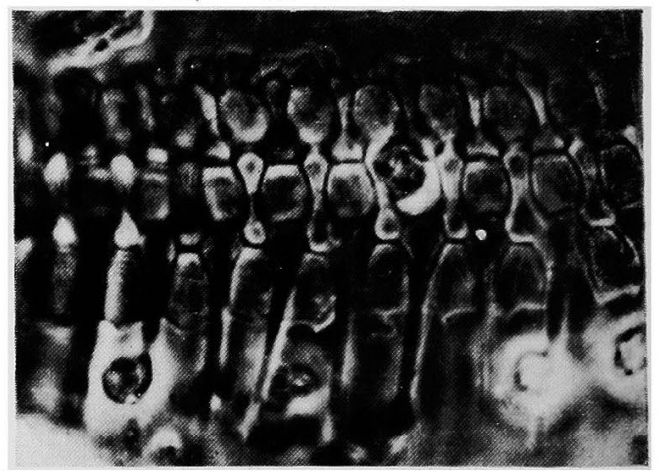


写直 12 網状膜と聴毛（基碟回枟）

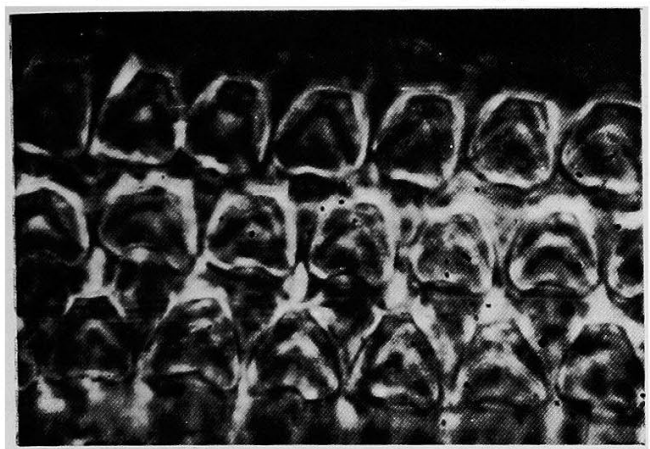

写真 14 外毛細胞聴毛（中央 回枟) $(2000 \times 2.5)$

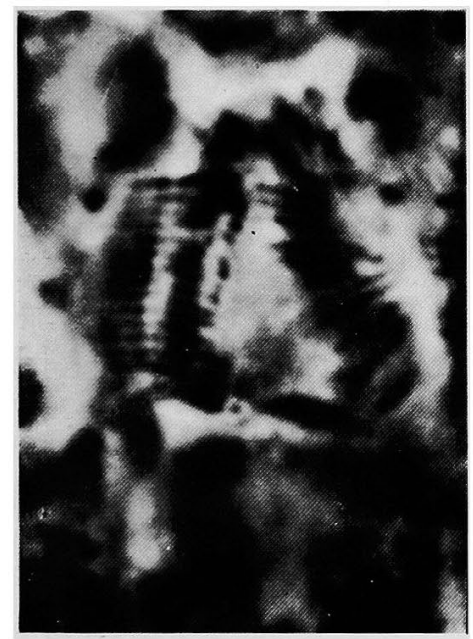

写真 16 内毛細胞聴毛 (長毛) (中央回枟)

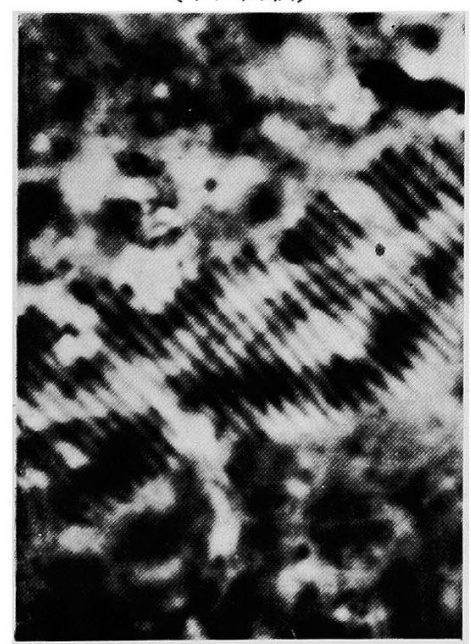

写真 13 外毛細胞德毛(尖端

回枟) $(2000 \times 2.5)$

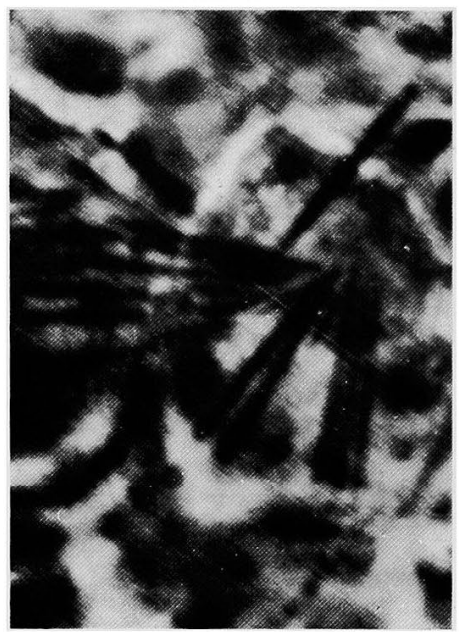

写真 15 外毛細胞聴毛（基礎 回枟) $(2000 \times 2.5)$

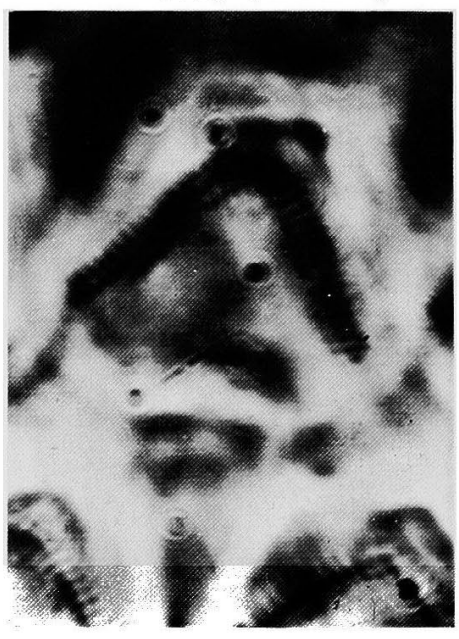

写真 17 同庄 (短毛) $(2000 \times 2.5)$

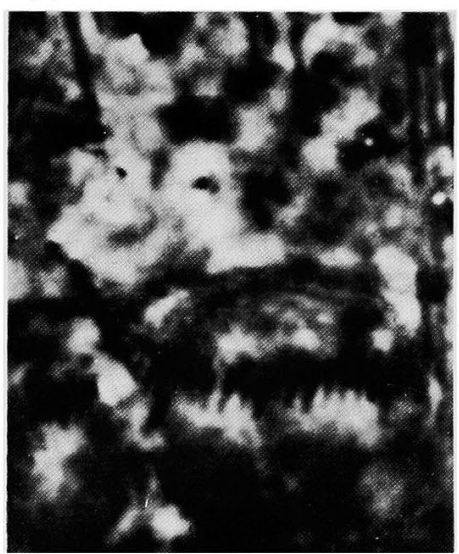


渡辺論文付図（IV）

写真 18 基礎膜（尖端回枟）

$(800 \times)$

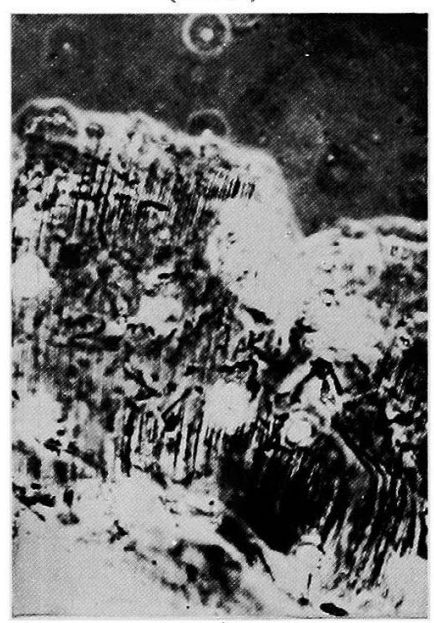

写真 20 コルテ膜 $(800 x)$

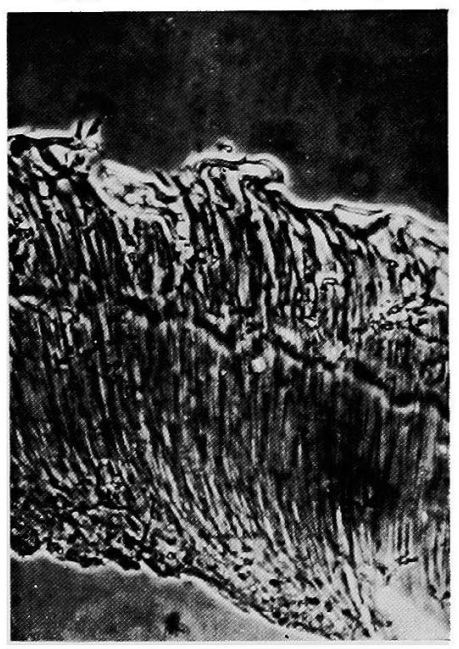

写真 22 脈 管 帯 $(800 x)$

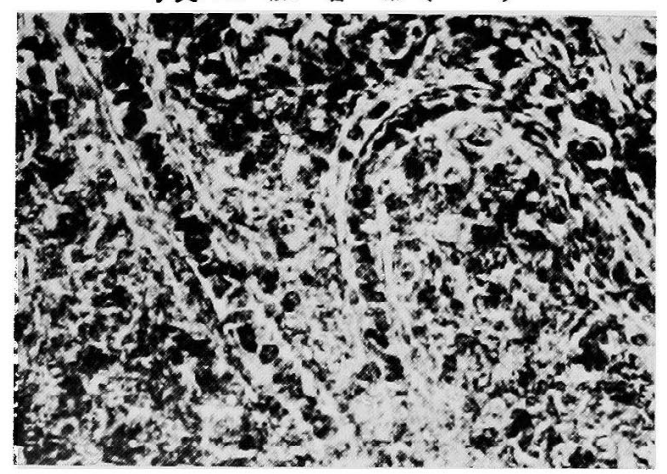

写真 19 基碟膜（基礎回枟）(800×）

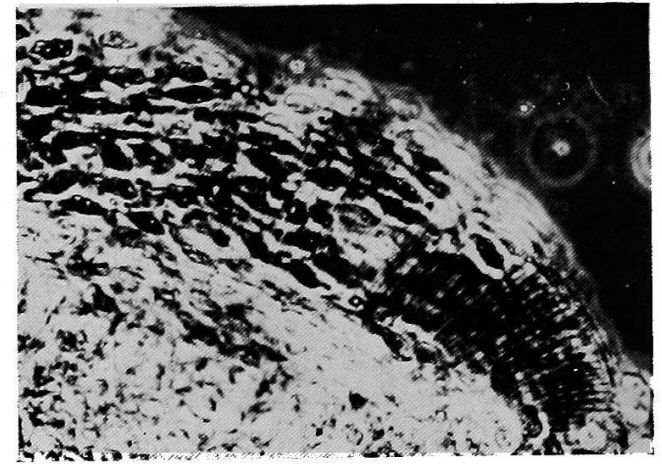

写真 21 エルチ膜の網状構造 $(1500 \times)$

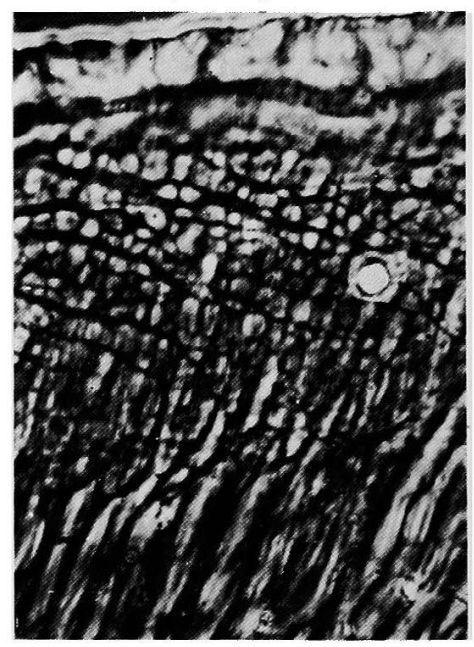

写真 23 ライスネル氏膜 $(800 \times)$

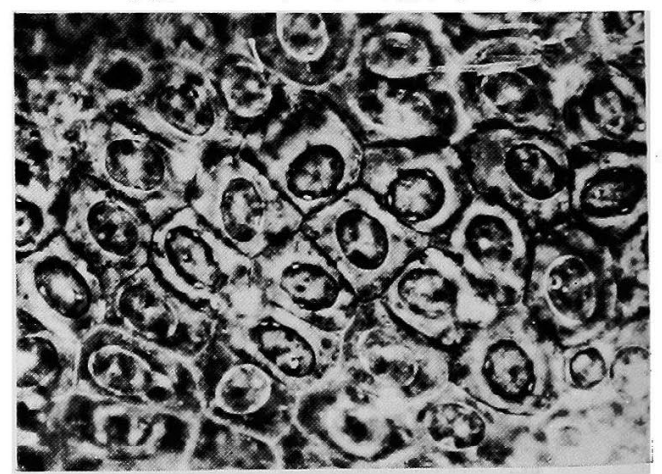

